\title{
INTRODUCTION: THE FOUNDATIONS OF A EUROPEAN LEGAL METHOD
}

\section{Sanne Taekema}

The methods of legal scholarship today are not self-evident. There are various reasons for the growing self-consciousness of legal scholars about their methodology. One of these is the internationalisation of legal research, which among other things has generated a change in the culture of legal publication towards peer-reviewed journals with stricter norms for methodological justification. Another reason is the weakening link between academic legal scholarship and national legal practice, which raises questions about the identity of legal scholarship as something distinct from legal practice and the extent to which methods define legal scholarship. A third reason is the popularity of interdisciplinary research in law, which gives lawyers reason to compare their own methods to those of other disciplines.

In many respects, the debate on legal method takes its cue from American debates about the character of legal research and the directions to be taken. This is visible, for instance, in the call for interdisciplinary research and in the still growing popularity of law and economics, both of which started in the American academic world.

However, there are also distinctly European developments, many of which we can connect to the Europeanisation of law in the context of the European Union. The expansion of the European Union has renewed the interest in the legal cultures of European countries, giving rise to comparative law research in the European context. In private law, ambitious projects abound proposing, for instance, pan-European legal norms of contract law. ${ }^{1}$ These themes involve exploring the differences and similarities in European legal systems and their cultural contexts.

In this issue of Erasmus Law Review, we take a step back from the study of the legal norms to look at European legal scholarship. The methods of legal scholarship are an underlying factor influencing the diversity of developments of legal systems. The divide between common law and civil law is not only visible in the particularities of the law in practice, but also in differing methodological approaches. For some comparative law scholars, the different style or mentalite of the common law and civil law approach is reason to be sceptical of all attempts to integrate law in Europe. ${ }^{2}$ The idea of this issue is to approach the possibility of a common European legal method with an open mind, with no prior commitment to either belief or scepticism.

To that end, we present general reflections on the history and present character of European legal scholarship. The central aim of the issue is the identification of common strands in the heritage of European legal scholarship that could serve as starting points for a common legal method in Europe. This question is approached from two angles, namely by studying the historical development of legal scholarship in Europe and by studying the philosophical basis of legal method.

Looking at legal method from a historical perspective, the acknowledged common thread of legal scholarship in Europe is the study of Roman law. In his contribution, Tammo Wallinga takes this as his starting point. However, he argues that Roman law was not the only common core: canon law was a second important component of legal scholarship that served to develop general legal concepts, accompanied by moral theology and the idea of natural law. Wallinga shows how legal scholarship in the universities on the European continent developed as a series of attempts at systematising law, mainly by applying logical and critical methods to the texts of the Corpus Iuris Civilis and Corpus Iuris Canonici, but also by criticising Roman law with the help of natural law principles.

See, for instance, the EU Commission's Green Paper of 1 July 2010 on policy options for progress towards a European Contract Law for consumers and businesses, COM (2010) 348.

Pierre Legrand, 'Against a European Civil Code' (1997) 60(1) The Modern Law Review 44 at 45. 
To this, two observations can be added. First, Wallinga's article shows the dynamics between sources of case law, which is essentially the nature of the Corpus Iuris Civilis, and general concepts of law. The desire to merge the two can be seen as the major impetus for a systematic legal method. Solving the difficulty of remaining true to the authoritative texts, while at the same time constructing general legal principles, has stimulated methodological creativity from the scholastic period until now. Secondly, the historical relationship between academia and legal practice merits attention. Currently, the close relationship between legal scholarship and legal practice is regarded suspiciously. The fact that legal methods in scholarship have largely been the same as those in, primarily, judicial practice is one reason why legal scholarship is not regarded as equal, academically, to other disciplines. Looking back to the Middle Ages, we can see that these methods actually originate in university teaching. The development of legal interpretation and argumentation started with the study of Roman texts. These academic achievements turned out to have practical relevance, although not all scholarly approaches were well received: humanism's historical and critical approach was an unwelcome challenge to textual authority.

Whereas Wallinga finds his point of departure in the historical practice of legal scholarship, Carel Smith in his article explores the philosophical basis of legal method. His main claim is that hermeneutics can be regarded as the paradigm, in Kuhn's sense, of legal scholarship. Hermeneutics is not itself a methodology for lawyers, but an account of the conditions for the understanding of law. Both legal doctrine and, more abstractly, legal theory are premised on the philosophical idea that understanding of law requires taking the internal, participant's point of view. Although the routes towards acknowledgement of this idea in legal theory are very different, Smith shows that the work of the European philosophers Gadamer and Wittgenstein can serve to explain the common underlying theory. The constraints for legal interpretation and research are social, bound up with institutions and interpretive communities.

These historical and philosophical reflections on legal scholarship and method yield an optimistic, albeit tentative, conclusion about the possibility of constructing a common European legal method. As Smith argues, the paradigm for legal theory is shared by Anglo-American and continental European theorists, which provides a basis on which to build a European legal method. However, this paradigm also encompasses the idea that culture is an important determinant of legal interpretation. If culture matters so much in law, the diversity in legal cultures may also influence, and interfere with, the development of a common method. Studying methodology in the context of legal cultures and the concrete possibilities for common ground would therefore be an interesting next step, building on the general work presented here. 